\title{
GRÜSS'S INEQUALITY, ITS PROBABILISTIC INTERPRETATION, AND A SHARPER BOUND
}

\author{
RIČARDAS ZITIKIS
}

Abstract. Motivated by statistical and actuarial applications of Grüss's inequality, we argue that the inequality can be sharpened if there is additional information about the mean values of the two functions in Grüss's inequality. In this sense, our research deviates from a large body of literature where Grüss's inequality has been sharpened by imposing more smoothness on the functions.

Mathematics subject classification (2000): 26D15, 60E15.

Keywords and phrases: Grüss inequality, covariance, mean, variance, inner space, Hilbert space, Hoeffding inequality.

\section{REFERENCES}

[1] Block, H. W. AND FAnG, Z., A multivariate extension of Hoeffding's lemma, Annals of Probability, 16 (1988), 1803-1820.

[2] Cerone, P., On a Čebyšev-type functional and Grüss-like bounds, Mathematical Inequalities and Applications, 9 (2006), 87-102.

[3] Denuit, M., Dhaene, J., Goovaerts, M. And KaAs, R., Actuarial Theory for Dependent Risks: Measures, Orders and Models, Wiley, Chichester, 2005.

[4] DRAGomir, S. S., A generalization of Grüss's inequality in inner product spaces and applications, Journal of Mathematical Analysis and Applications, 237 (1999), 74-82.

[5] DragomiR, S. S., Advances in Inequalities of the Schwarz, Grüss and Bessel Type in Inner Product Spaces, Nova Science Publishers, Hauppauge, New York, 2005.

[6] DRAGOMiR, S. S., Sharp Grüss-type inequalities for functions whose derivatives are of bounded variation, Journal of Inequalities in Pure and Applied Mathematics, 8, Article 117 (2007), 13 pp.

[7] Elezović, N., Marangunić, LJ. And PeČArić, J., Some improvements of Grüss type inequality, Journal of Mathematical Inequalities, 1 (2007), 425-436.

[8] GRÜSs, G., Über das maximum des absoluten betrages von $\frac{1}{b-a} \int_{a}^{b} f(x) g(x) d x-$ $\frac{1}{(b-a)^{2}} \int_{a}^{b} f(x) d x \int_{a}^{b} g(x) d x$, Mathematische Zeitschrift, 39 (1935), 215-226.

[9] HoefFding, W., Masstabinvariante korrelationstheorie, Schriften des Matematischen Instituts für Angewandte Matematik der Universität Berlin, 5 (1940), 179-233.

[10] MA, J., An identity in real inner product spaces, Journal of Inequalities in Pure and Applied Mathematics, 8, Article 48 (2007), 4 pp.

[11] Nelsen, R. B., An Introduction to Copulas. (2nd edition.) Springer, New York, 2006. 